\title{
Cell-Derived Microparticles: New Targets in the Therapeutic Management of Disease
}

\author{
Ariane Roseblade ${ }^{\mathrm{a}}$, Frederick Luk ${ }^{\mathrm{a}}$, Tristan Rawling ${ }^{\mathrm{a}}$, Alison Ung ${ }^{\mathrm{b}}$, Georges E. R. Grau ${ }^{\mathrm{c}}$, Mary Bebawy \\ ${ }^{a}$ School of Pharmacy, Graduate School of Health, The University of Technology, Sydney, NSW, Australia; ${ }^{b}$ School of \\ Chemistry and Forensic Science, Faculty of Science, The University of Technology, Sydney, NSW, Australia; ${ }^{c}$ \\ Vascular Immunology Unit, Sydney Medical School and Bosch Institute, The University of Sydney, NSW, Australia \\ Received, May 17, 2013; Revised, May 30, 2013; Accepted, May 30, 2013; Published, May 30, 2013.
}

\begin{abstract}
Intercellular communication is essential to maintain vital physiological activities and to regulate the organism's phenotype. There are a number of ways in which cells communicate with one another. This can occur via autocrine signaling, endocrine signaling or by the transfer of molecular mediators across gap junctions. More recently communication via microvesicular shedding has gained important recognition as a significant pathway by which cells can coordinate the spread and dominance of selective traits within a population. Through this communication apparatus, cells can now acquire and secure a survival advantage, particularly in the context of malignant disease. This review aims to highlight some of the functions and implications of microparticles in physiology of various disease states, and present a novel therapeutic strategy through the regulation of microparticle production.
\end{abstract}

This article is open to POST-PUBLICATION REVIEW. Registered readers (see "For Readers") may comment by clicking on ABSTRACT on the issue's contents page.

\section{INTRODUCTION}

Microvesicles are shed from most eukaryotic cells, and serve as vectors of long and short range signaling, facilitating the exchange of cargo between donor and recipient cells (1-4). Various microvesicles have been defined, including microparticles (MPs), exosomes and apoptotic bodies, with each vesicle type expressing distinct biochemical and structural characteristics $(5,6)$.

\section{Microvesicle Classification}

\section{Microparticles}

MPs are small enclosed plasma membrane fragments, measuring $0.1-1 \mu \mathrm{m}$ in diameter, that typically express phosphatidylserine (PS) on their surface (2).

MPs are released from pre-apoptotic and activated cells by outward blebbing and vesiculation of the plasma membrane following a breakdown of the cytoskeleton, and play a central role in extracellular communication, inflammation, thrombosis, vascular function and oncogenic transformation (4, 7-13).

MPs are emerging as messengers for cells, whereby they can alter vascular function and induce various biological responses (14-16). In their role as messengers, MPs carry molecular components of the parent cell such as membrane proteins, cytokines, integrins, transcription factors, nucleic acids and cytoplasmic contents, and can alter the activity of recipient cells through the transfer of their cargo $(3,4,17,18)$. This capacity has been implicated in long range cell signaling, coagulation, apoptosis, immune modulation, drug resistance and disease (19-24).

\section{Apoptotic Bodies}

Apoptosis leads to the formation of apoptotic bodies, which are membrane-enclosed cell fragments similar in size to platelets $(1-5 \mu \mathrm{m}$ in diameter) (25). These fragments consist of cytoplasm, organelles and nuclear fragments and are implicated in cancer progression and immunosuppression (26-29). Apoptotic bodies externalise PS to promote phagocytosis and removal $(26,30-32)$.

\section{Exosomes}

Exosomes are a smaller and more homogenous population of microvesicles, measuring 0.04-0.1 $\mu \mathrm{m}$ in diameter (approximately same size as viruses) that are released by the exocytosis of multivesicular

\footnotetext{
Corresponding Author: A/Prof Mary Bebawy; School of Pharmacy, The University of Technology, Sydney, Broadway, NSW 2007, Australia; Email: mary.bebawy@uts.edu.au
} 
bodies, and are formed by inward budding into the lumen at the endosomal limiting membrane $(2,33,34)$. These multivesicular bodies fuse with the plasma membrane to release the small vesicles inside (the exosomes). Exosomes are released by most cell types, and contain cytosolic components, such as tetraspanin proteins, ribonucleic acids (RNAs), as well as cell surface proteins $(2,13,35-38)$.

After being released from their respective cells, exosomes will either remain in the proximity of the cell of origin or relocate to biological fluids such as plasma, urine, milk, bronchoalveolar fluid and tumour effusions, and thereby facilitate long-range biological signaling (39-43).

\section{Formation of Membrane-derived Microparticles}

As platelet MPs have been the most widely studied vesicles thus far, the majority of information regarding MP shedding is in the context of activated platelets. The mechanisms involved however are believed to be similar for most cell types $(44,45)$.

Cell activation leading to MP formation is attributed to various stimuli such as serine proteases, thrombin, ADP, inflammatory cytokines (e.g. TNF), growth factors, shear and stress inducers (46-51). In contrast to this, apoptosis-induced MP release is regulated by the caspase-mediated Rho effector protein 'Rhoassociated, coiled-coil containing protein kinase 1' (ROCK 1), and can also be stimulated by TNF and thrombin (50).

\section{Disruption of Phospholipid Asymmetry}

MPs are formed following disruption of the cell's phospholipid asymmetry (52-54). Under steady state conditions, phosphatidylcholine (PC) and sphingomyelin (SM) are located predominately on the outer membrane leaflet, and PS and phosphatidylethanolamine (PE) are located on the inner membrane leaflet $(55,56)$. This asymmetric distribution is under the control of the membranebound ATP-dependent enzymes; flippase and floppase, as well as the ATP-independent transporter scramblase (Figure 1) (57, 58). Flippase (the aminophospholipid translocase) rapidly directs phospholipids, specifically PS and $\mathrm{PE}$, to the inner leaflet, whereas floppase promotes the much slower outward translocation of lipids (9). Scramblase is a bidirectional transporter and promotes random distribution of phospholipids across the plasma membrane bilayer $(56,59)$.

Membrane reorganisation can occur under normal physiological conditions or in response to stimuli, such as following exposure to proinflammatory or prothrombotic substances, and involves the calcium-dependent inhibition of flippase and the promotion of scramblase and floppase activity $(46,56,60)$. During this process, phospholipids, such as PS, are redistributed from the inner leaflet of the plasma membrane to the outer leaflet $(9,56,61)$.

\section{Membrane Vesiculation and the Role of Calpain}

Following loss of phospholipid asymmetry, the anchorage between the membrane and cytoskeleton is disrupted. This allows for membrane vesiculation and subsequent MP release $(45,62)$.

In the case of apoptosis-induced MP release, the process is regulated via the activation of ROCK 1. During apoptosis, activated caspases (cysteine proteases associated with apoptosis) cleave ROCK 1, which promotes the generation of contractile force that leads to the formation of membrane blebs, disruption of the cellular membrane structure and subsequent vesiculation $(9,48,63)$.

Conversely, the release of MPs from activated cells is associated with the activity of calpains. Calpains are intracellular cysteine proteinases, found in almost all eukaryotes and some prokaryotes, and play a central role in cellular functions such as cell cycle progression, gene expression, cytoskeleton cleavage, signal transduction, cell proliferation and MP formation (64-66). Calpain resides in the cytosol in its inactive form until an increase in cytosolic calcium translocates it to the cellular membrane where it is then activated (64).

After phospholipid scrambling, calpain cleaves cytoskeletal talin and $\alpha$-actin filaments that adhere the plasma membrane to the cytoskeleton, thereby allowing the release of MPs (Figure 2) (53, 67, 68).

The calpain family consists of both tissuespecific and ubiquitously expressed isoforms. The best characterised isoforms are the ubiquitously expressed $\mu$-calpain and $m$-calpain, which are named according to the concentrations of $\mathrm{Ca}^{2+}$ required to activate them in vitro; micromolar for $\mu$-calpain and millimolar for $m$-calpain $(69,70)$. 

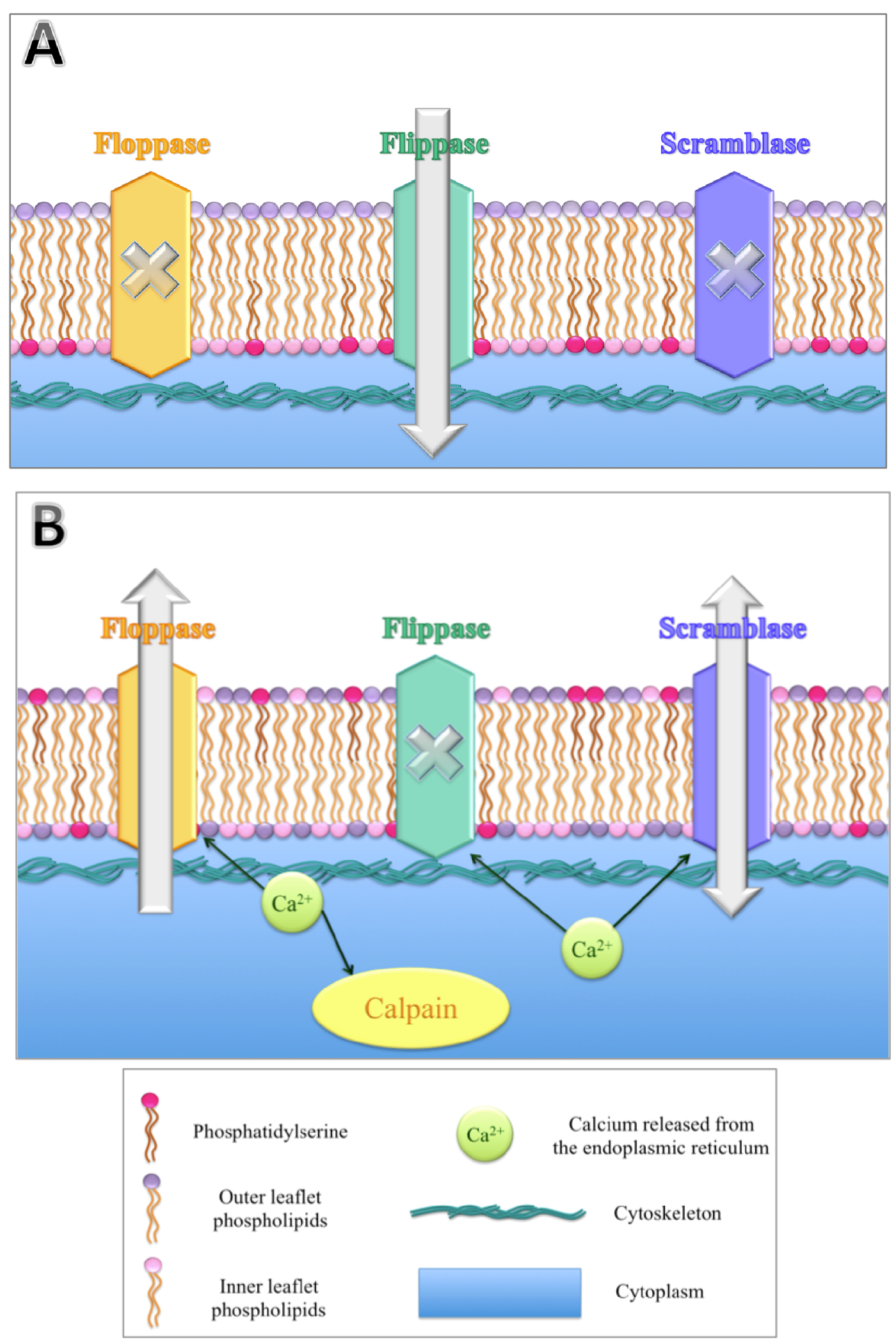

Figure 1. A) Schematic of a cellular membrane at rest. Phospholipid asymmetry is under the control of active flippase, whilst floppase and scramblase remain inactive. B) Cellular activation. Calcium is released from the endoplasmic reticulum, which can lead to the loss of phospholipid asymmetry and the activation of calpain. 


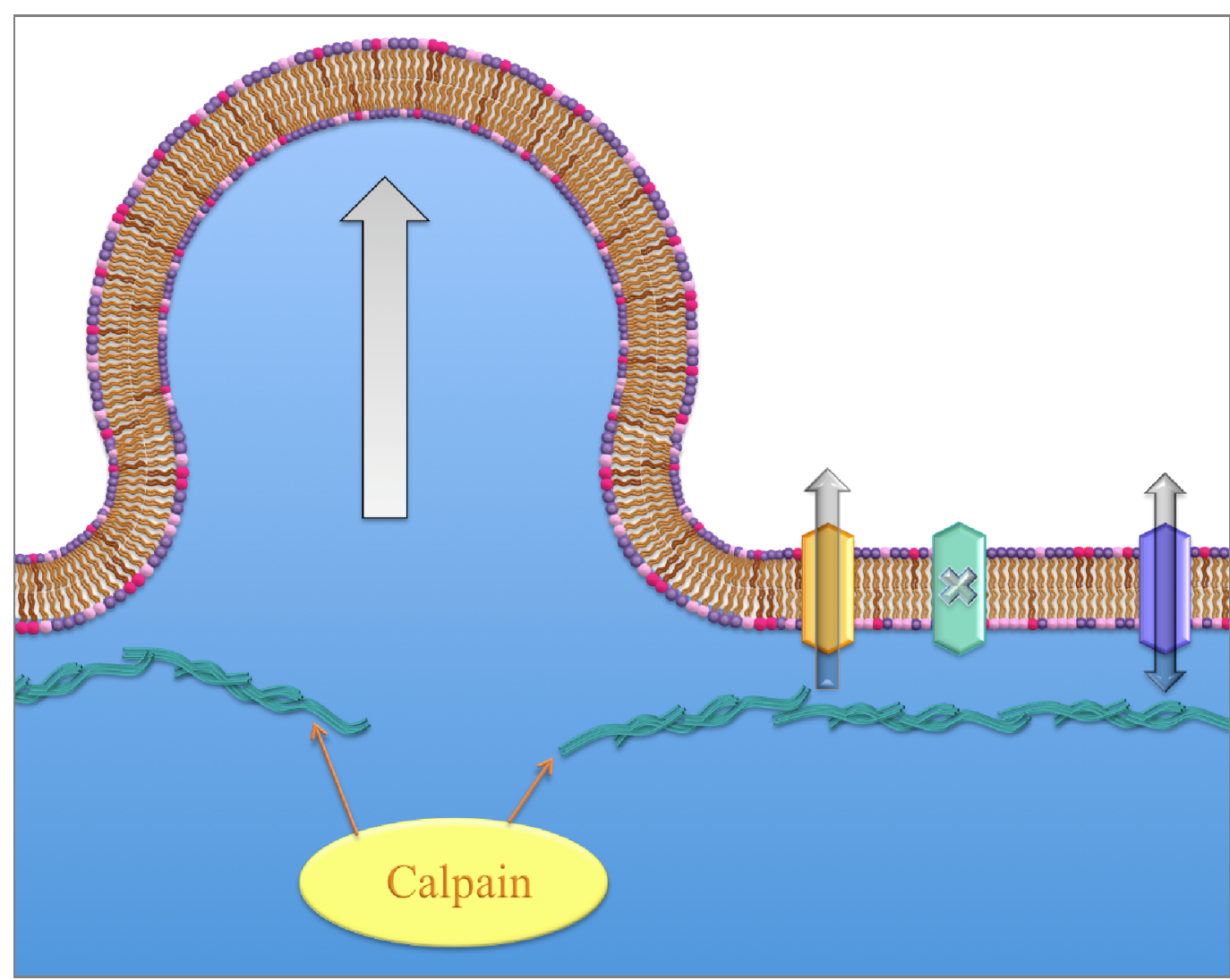

Figure 2. Cytoskeleton disruption. Activated Calpain cleaves the cytoskeleton, leading to the formation of a membrane bleb and subsequent MP release.

These proteins function as hetero dimers and are composed of large $80 \mathrm{kDa}$ catalytic subunits and a small common $28 \mathrm{kDa}$ regulatory subunit. $\mu$ calpain is encoded by the gene $C A P N 1$, and $m$ calpain is encoded by $C A P N$ 2, with the common regulatory subunit being encoded by $C A P N 4$. This small subunit is identical for both enzymes and the large subunits share $55-65 \%$ sequence homology $(64,69,71)$.

Both $\mu$-calpain and $m$-calpain can be subdivided into four domains. Domain II is the catalytic domain, conserved in all calpain isoforms, and is a triad site, which contains cysteine, histidine and asparagine residues. In human $\mu$-calpain cysteine is located at residue 115 , while in $m$-calpain it is located at residue 105 (69).

Calpain activity is tightly regulated by calpastatin, the endogenous inhibitor of $\mu$-calpain and $m$-calpain and other dimeric calpains $(65,72)$. Calpastatin is a ubiquitously expressed inhibitor with four inhibitory domains, that displays specificity for calpain over other cysteine proteases, and can reversibly inhibit up to four molecules of calpain at once by blocking the active sites of calpain $(65,69,72)$.

\section{The Role of Microparticles in Homeostasis}

MPs play an important role in biological processes such as coagulation, intercellular communication, apoptosis and homeostasis (48, 73, 74).

Platelet and endothelial MPs circulating in blood express PS and tissue factor (TF) (the primary initiator of the extrinsic coagulation pathway) on their outer membrane. This exposed PS and TF provides a procoagulant surface for clotting enzymes in the coagulation cascade and therefore enables optimal thrombin generation $(18,75)$.

A crucial role for MPs in clot formation has been demonstrated in vivo, using a mouse model of haemophilia (76). In this setting, as well as in human blood, procoagulant MP were generated by the interaction of P-selectin and its natural ligand, PSGL-1. 
MPs have been reported to express anticoagulant properties to balance their procoagulant activity. MPs indirectly downregulate thrombin generation by promoting the generation of plasmin, and thus maintain vascular integrity (77-79).

MP-mediated cell signaling has also been implicated in the maintenance of homeostasis, with miRNAs that are predicted to regulate homeostasis and metabolic function being found in MPs circulating in the plasma of healthy donors (80).

\section{Microparticles in Disease}

\section{Scott Syndrome}

Reduced MP levels have been implicated in the physiological dysfunction seen in Scott syndrome, a very rare autosomal disorder, and the only human disease known to be caused by a lack of MP formation. This disorder is characterised by platelets, red blood cells and B-lymphoblasts lacking the ability to externalize PS and release MPs due to the abnormal expression of scramblase $(2,47,57)$. The absence of PS exposure in this disorder results in severe bleeding due to impaired thrombin generation (47).

\section{HIV-1}

In a seminal study by Mack et al. it was shown that MPs disseminate specific chemokine receptors required for the propagation of HIV-1 to receptor-negative cells (20). In order to infect target cells HIV-1 requires the expression of CD4, an immune cell glycoprotein, and virus coreceptors which enable target cell binding and internalisation of viral particles (81). It was shown that various cell types release MPs containing the chemokine CCR5. These MPs are then able to transfer the receptor to CCR5 cells and render them susceptible to HIV-1 infection. This transfer and acquisition demonstrated the important role that MPs play in the dissemination of deleterious traits (20).

\section{Diabetes}

Vascular disorder is closely linked to type 2 diabetes, with $50 \%$ of diabetic deaths being attributed to cardiovascular disease (82).

MP formation associated with type 2 diabetes has been implicated in the enhancement of thrombin generation and procoagulant activity, with endothelial-derived MPs and monocytederived MPs reported to participate in the development of atherosclerosis in hyperlipidemic diabetic patients (83). With such a high death rate associated with symptoms secondary to the main disease, the modulation of MP release in the progression of diabetes could potentially help to circumvent the development of cardiovascular complications (83).

\section{Cerebral Malaria}

Malaria is a life threatening disease caused by Plasmodium parasites that is estimated to cause up to 1 million deaths per year (84).

Blood-borne Plasmodium falciparum is the most deadly species, and infection induces profound changes in the microvasculature, including TNF production, which leads to platelet adhesion, formation of endothelial-derived MPs, cerebral vascular inflammation and microcirculatory dysfunction (85-87).

Patients with severe malaria exhibit increased plasma levels of endothelial MPs. Remarkably, these high levels were seen in the presence of neurological complications - a syndrome called cerebral malaria $(\mathrm{CM})$ - but not in patients presenting only severe malarial anaemia.

In $\mathrm{CM}$, the major deleterious effects are not only attributed to the degree of infection itself, but to immune cell over-activation, resulting notably in cytokine storm, platelet activation and enhanced MP formation from various cellular origins $(85,87,88)$.

In the experimental model for $\mathrm{CM}, \mathrm{ABCA1}^{-/-}$ mice, which lack the floppase transporter required to externalise PS on MPs, were found to exhibit minimal vesiculation and complete resistance to $\mathrm{CM}$, which suggests that MPs are directly implicated in the progression of the neurovascular pathology $(14,89,90)$.

In $\mathrm{CM}$, increased release of MPs correlated with the acute phase of the condition and is a potentially useful diagnostic tool and patient management aid, as MP levels associated with acute neurological phase returned to normal levels during recovery $(88,91)$.

Studies have concluded that the cellular origin, amount and composition of MPs can reflect the pathophysiological state and therefore could be used as diagnostic markers to monitor disease (91). 


\section{Cancer}

Cancer-derived MPs were first reported in 1978 when they were detected in cultures from a patient with Hodgkin disease (92). Tumour cells can produce MP constitutively without any apparent need for stimulus but vesiculation can be increased by stress including exposure to chemotherapeutic drugs and heat (6).

Cancer patients not only exhibit tumourderived MP but also high levels of plateletderived MP (93). The hypercoagulation typically observed with malignancy can be attributed in part to these procoagulant MPs $(94,95)$.

MPs have been shown to contribute to tumour survival and it has been postulated that tumour cells can evade apoptosis by releasing MPs that contain caspase-3, thereby preventing its intracellular accumulation (96). Inhibition of this release has been shown to result in caspase-3 accumulation and subsequent apoptosis (96).

To facilitate invasion, metastatic cancer cells can degrade the extracellular matrix (ECM) through the transfer of surface proteases such as matrix metalloproteinases (MMPs), urokinasetype plasminogen activator (uPA) and cathepsins (97). Tumour cells have been shown to release MP rich in MMPs and UPA, which degrade the ECM, allowing for cell invasion (98).

Tumour-derived MPs also carry regulatory miRNAs, mRNAs and bioactive lipids, and can transmit them to other cells within the body $(4,6$, 99, 100). Of particular concern is the MP assisted dissemination of cancer multidrug resistance, by which drug sensitive cells can acquire the resistance phenotype via long-range communication $(3,23)$.

\section{Multidrug Resistance}

Multidrug resistance (MDR) is the phenomenon by which cancers become cross-resistant to a wide variety of functionally and structurally unrelated chemotherapeutic drugs and constitutes the most significant obstacle in successful cancer treatment $(100,101)$.

MDR is predominately associated with the over-expression of the multidrug efflux transporters $\mathrm{P}$-glycoprotein $(\mathrm{P}-\mathrm{gp} / A B C B 1)$ and Multidrug Resistance-Associated Protein 1 (MRP1/ABCC1), which are both expressed in the cell membrane of resistant cancer cells (102). These transporters belong to the superfamily of ATP-binding cassette $(\mathrm{ABC})$ proteins which have also been implicated in infectious diseases such as AIDS and malaria $(86,89,103,104)$. P-gp and
MRP1 enable the maintenance of sublethal intracellular concentrations of chemotherapeutic drugs by facilitating the ATP-dependent efflux of anticancer agents, allowing the tumour to evade the toxic insult (100, 101, 104-107).

The mechanism that allows these transporters to bind and efflux a broad repertoire of drugs remains as yet undefined. Since the discovery in 1981 that verapamil and trifluoperazine could positively affect MDR by the modulation of P-gp, hundreds of drugs with different structures and activities, such as immunosuppressants, calcium channel blockers and steroids have been developed (108-110). Inhibitors of P-gp have been investigated in the prevention or circumvention of MDR clinically, with many showing positive effects in vitro, but proving to be unsuitable clinically due to dose limiting toxicity and lack of efficacy $(111,112)$.

\section{Microparticle Mediated MDR}

The over-expression of P-gp is known to be controlled by genetic and epigenetic mechanisms, and MDR acquisition through this process has been well characterised $(113,114)$. The spread of P-gp mediated MDR through non-genetic pathways however has been more recently reported, with direct membrane protein transfer occurring through direct cell-to-cell contact, shed MPs and tunneling nanotubles $(23,115)$.

'Non-genetic' acquisition of MDR was first demonstrated by Levchenko et al. through direct cell-to-cell contact (116). It was shown that P-gp could be transferred from P-gp positive cells to Pgp negative cells via direct cell-to-cell contact both in in vitro and in vivo, allowing previously drug-sensitive tumour cells to survive exposure to toxic levels of chemotherapeutic drugs. The acquired phenotype was transient in vivo, and required constant exposure to anti-cancer drugs or P-gp positive cells (116).

Our laboratory was the first to report that MDR can be spread in the absence of cell-to-cell contact with MPs being shown to facilitate the 'non-genetic' transfer of MDR from drugresistant cells to drug-sensitive cells (23). We observed that MPs (i) were spontaneously shed from P-gp expressing leukemia cells $\left(\mathrm{VLB}_{100}\right)$, (ii) carry P-gp from the donor cells, (iii) bind to and transfer P-gp to recipient cells and (iv) confer the multidrug resistance phenotype to drug sensitive cells in vitro in as little as four hours following MP exposure (23).

Further investigation revealed that MDR breast adenocarcinoma cells (MCF-7/DX) also 
spontaneously shed MP bearing functional P-gp and can confer the resistance phenotype to drugsensitive recipient cells, demonstrating that cancerous cells of both haematological and nonhaematological origin are able to transfer MDR via this pathway (100).

Validation of this MP mediated pathway was demonstrated in vivo using the MCF-7 murine tumour xenograph model. A single subcutaneous injection of P-gp positive MPs administered adjacent to the tumour mass, effectively resulted in the transfer of P-gp to the tumour core as early as 24 hours later. This acquired phenotype remained stable for at least two weeks without MP re-administration or exposure to a selective pressure (3).

In a recent study we also showed that MPs exhibit tissue selectivity, with respect to the transfer of P-gp to recipient cells. MPs derived from P-gp over-expressing breast adenocarcinoma cells (MCF-7/DX cells) selectively transfered P- gp to malignant MCF-7 breast cells only. Conversely, MPs derived from P-gp overexpressing human leukaemia cells $\left(\mathrm{VLB}_{100}\right.$ cells) transferred P-gp and MRP1 to both malignant and non-malignant cells (3). This study demonstrates for the first time a tissue selective component in the transfer of MP cargo.

MP also mediate the transfer of regulatory nucleic acids from drug-resistant cells to drugsensitive cells, and re-template the transcriptional landscape of recipient cells to reflect the donor cell (Figure 3) $(4,100)$. Further to this, we have shown that MPs transfer the transcripts that encode floppase and scramblase to recipient cells in vitro, as well as enzymes that are essential for miRNAs biogenesis (Drosha, Dicer and Argonaute) (4). The presence of these transcripts suggests that MPs could be capable of inducing vesiculation in recipient cells, as well as being key regulators of intercellular miRNA biogenesis.

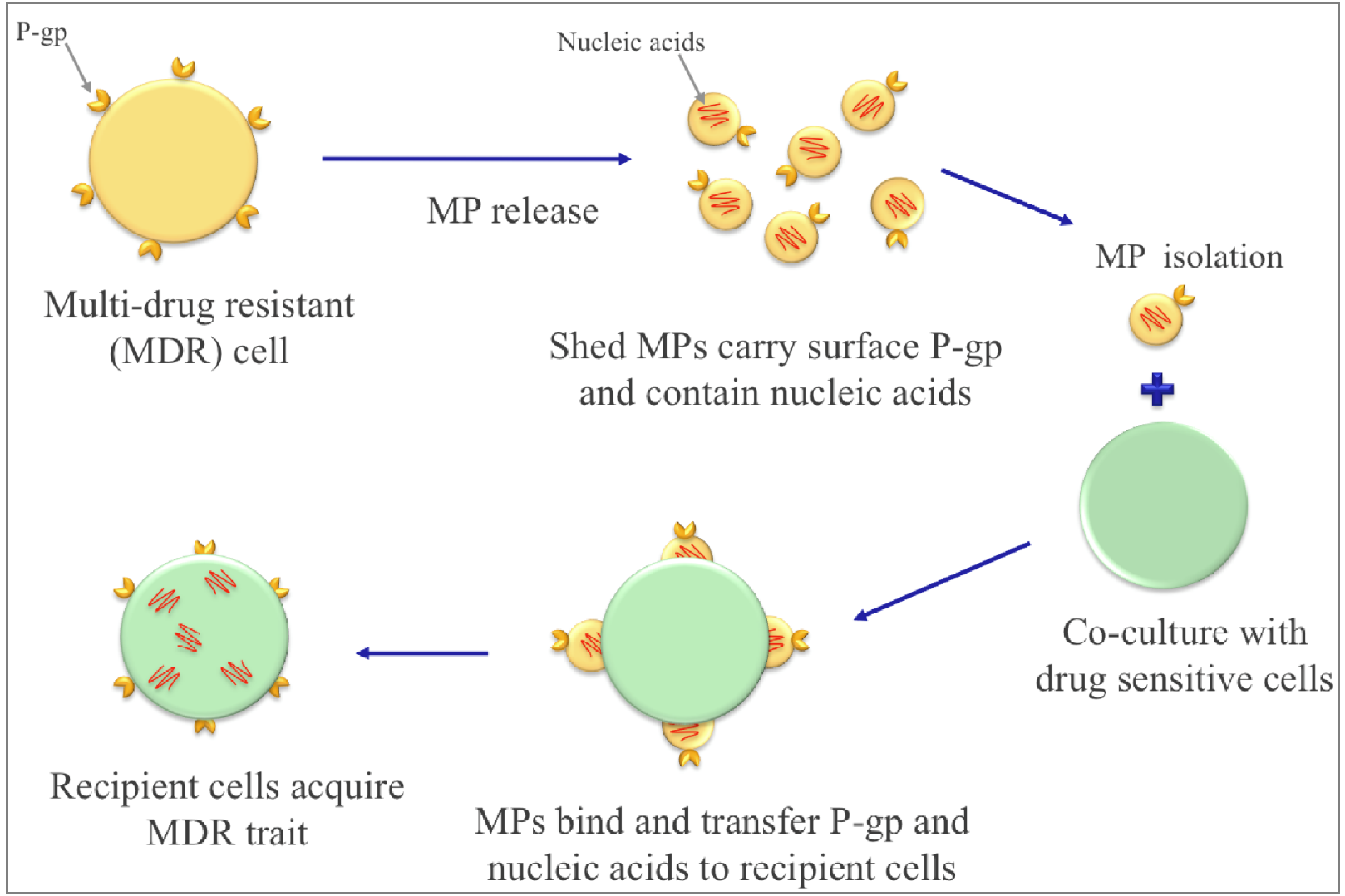

Figure 3. Mechanism for MP-conferred MDR in vitro. MPs, containing functional P-gp and nucleic acids, are released from multidrug resistant cells. MPs are then co-cultured with resistant cells. MPs confer MDR to drug-sensitive cells. 


\section{Microparticle Inhibitors}

It has been well established that MPs actively contribute to the development and progression of numerous pathologies $(2,117)$. Modulation of their release therefore has the potential to provide a novel pharmacological strategy for disease state management.

There are currently a variety of inhibitors that have been identified as providing therapeutic potential in this regard. These include inhibitors of calpain activation, calcium channel blockers and various small molecule inhibitors.

\section{Calpain Inhibitors}

Due to the critical role calpain plays in MP release, targeting of calpain is a promising strategy to inhibit MP production. The development of potent and selective calpain inhibitors has received significant attention, as calpain has been implicated in several pathophysiological conditions including cerebral ischemia, Alzheimer's disease, Parkinson's disease, muscular dystrophy, thrombotic platelet aggregation, multiple sclerosis and diabetes, $(68$, $70,118,119)$. Unfortunately, most of this work has not examined the effects on MP production.

In the following section we provide a general outline of calpain inhibitors, and then focus on developments made in the context of inhibition of MP production.

Calpain inhibitors generally target the thiolcontaining cysteine residue within the enzyme's catalytic domain. These inhibitors are broadly classified as reversible or irreversible depending on how they interact with cysteine, with both classes containing an electrophilic center, also referred to as a 'warhead'.

Reversible warheads include $\alpha$-ketoesters, $\alpha$ ketoamides and aldehydes, which all form a hemithioacetal or ketal with the cysteine thiol (120-122).

Irreversible warheads such as epoxides, $\alpha$ haloketones, vinyl sulfone and diazomethyl ketone form irreversible covalent adducts (123125). Irreversible inhibitors have received less attention in drug discovery due to the potential for unexpected or undesirable effects during treatment, as irreversible inhibition of calpainactivated cell-cycle progression, for example, could potentially have deleterious outcomes (118, 126).

In both classes, the warheads are commonly attached to a peptide backbone that is structurally similar to endogenous substrates, thus assisting in binding to calpain's catalytic site and correctly positioning the warhead near the cysteine residue (127). A drawback to these peptidyl inhibitors is that rapid degradation by proteinases likely limits their in vivo efficacy. To circumvent this, several peptidomimetic inhibitors have been developed, however reactivity and metabolic instability of the warhead, as well as low calpain isoform selectivity remain issues for these inhibitor classes (128). Allosteric inhibitors of calpain have also been developed and show promise as selective inhibitors with improved pharmacokinetic properties $(129,130)$. These non-peptide inhibitors bind at the regulatory calcium-binding domain and prevent conformational changes required to activate calpain $(69,72)$.

As over-active calpain can induce aberrant MP release, potential inhibitors of its activity have been investigated in order to develop a novel treatment method for related disease states.

The calpain inhibitors MDL-28170 (a peptidyl aldehyde) and E-64-D (a peptidyl epoxide), (Figure 4) have been shown to significantly reduce MP release from platelets activated by agonists such as calcium ionophore A23187, thrombin and collagen (131). Likewise, calpeptin $(200 \mu \mathrm{g} / \mathrm{mL})$, a membrane-permeable inhibitor, has been shown to strongly inhibit the generation of MPs $(\sim 70 \%)$ from thrombin and collagen activated platelets in vitro, by inhibiting calpain activity as well as intracellular calcium elevation and attenuating thrombotic effects (67, 132). Due to their inhibitory activities these compounds have shown some potential as treatment options for MP-related conditions, however these compounds lack specificity for calpain $(131,133)$.

Thiosulfinates are another class of compounds that have been shown to inhibit calpain (134). These compounds occur naturally in different Allium species (such as onion and garlic), vegetables that have been shown to have beneficial health effects in conditions such as hypertension, inflammation, cardiac disease and cancer (135). Three members of the thiosulfinate family allicin, $\operatorname{Pr}_{2} \mathrm{TS}$ and $\mathrm{Me}_{2} \mathrm{TS}$ (Figure 4) were shown to inhibit calpain activation in platelets, leading to potent anti-aggregation activities with $\mathrm{IC}_{50}$ 's between $9-15 \mu \mathrm{M}$ (119). Inhibition of aggregation was attributed to reduced calpainmediated talin activation and reduction in platelet MP production: at $100 \mu \mathrm{M}$ MP production was strongly inhibited. 


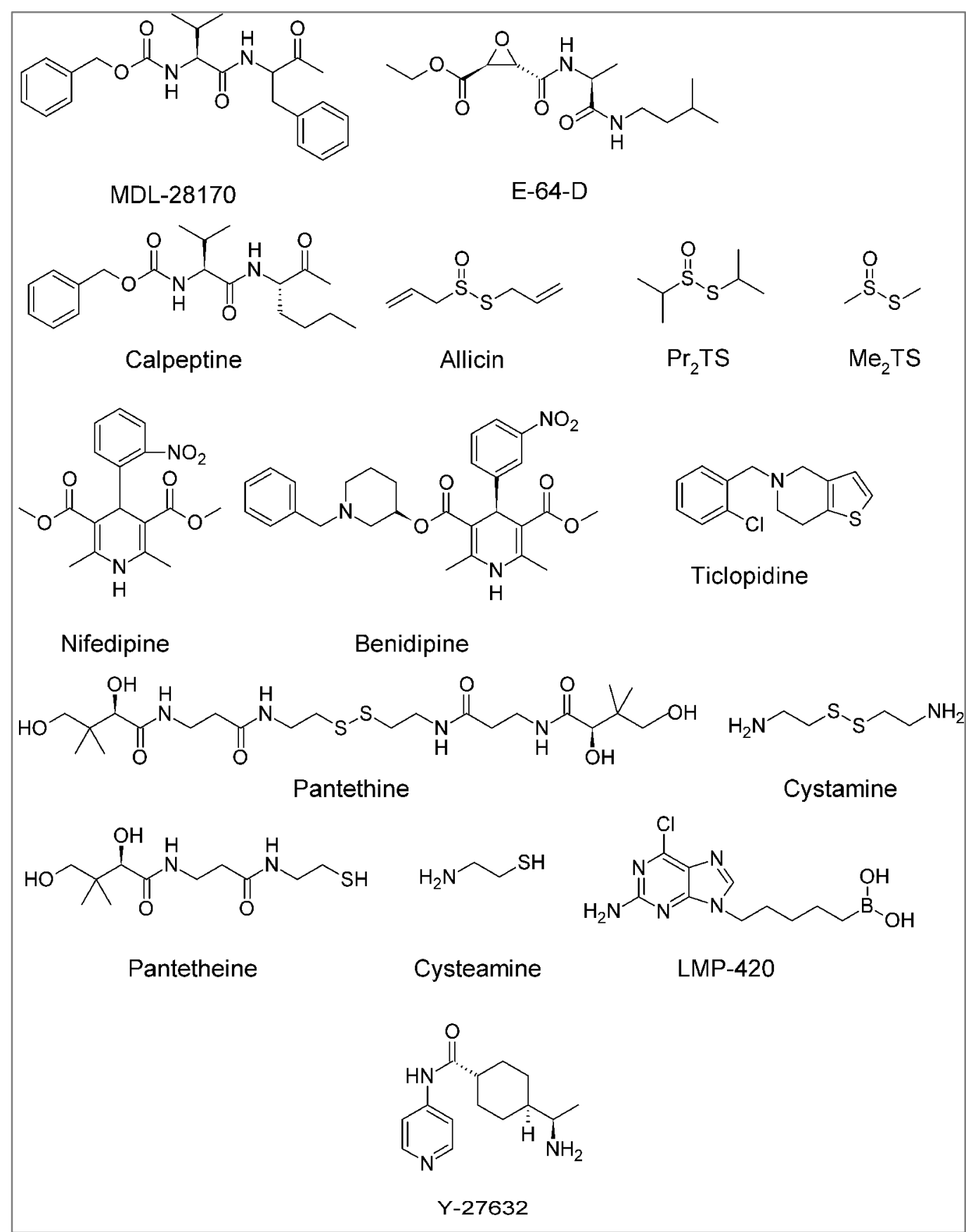

Figure 4. A selection of compounds reported to inhibit the formation of MPs

\section{Calcium Channel Blockers}

An increase in intracellular calcium plays a key role in MP generation, thus inhibition of cellular calcium influx is another strategy used to decrease MP production. Indeed, the calcium channel blockers nifedipine and benidipine, developed to treat hypertension, are effective in reducing MP release by thrombin-activated platelets in patients suffering from transient ischemic attacks (TIA).

Elevated levels of circulating platelet MP are observed in patients with TIA and are associated with small vessel thrombosis $(136,137)$. Nifedipine (30-60 mg/day), a dihydropyridine calcium channel blocker (Figure 4), decreased cytosolic calcium concentrations and was shown to significantly reduce platelet MP levels $(\sim 50 \%)$ 
in patients exhibiting TIA symptoms (138). As a short-term treatment, the administration of this drug to patients with TIA was shown to reduce the concentration of MPs in the circulation, however the drug did not appear to be a viable long-term treatment option as many of the patients suffered a recurrence of TIA whilst taking the drug $(136,138)$. Benidipine (4 $\mathrm{mg} /$ day), also a dihydropyridine calcium channel blocker (Figure 4), was administered over a sixmonth study to patients with diabetes mellitus to improve vascular dysfunction associated with monocyte and endothelial cell hypercoagulability. The administration of this drug resulted in decreased patient MP levels, and was shown to lower the blood pressure in hypertensive patients. (139). Whilst the outcomes for these drugs were positive, the patient MP levels were still much higher than in the healthy controls involved in the study $(138,139)$. This would suggest that whilst the effects are beneficial, further development of this class of drug is needed to effectively treat MP-associated symptoms.

\section{Anti-platelet Drugs}

Compared to healthy individuals, diabetic patients have increased levels of platelet-derived MPs (PDMPs) and monocyte-derived MPs (MDMPs), with both types of MPs promoting procoagulant activity (140). Ticlopidine (Figure 4), a thienopyridine antiplatelet drug used in the treatment of arteriosclerosis obliterans, has been identified for the treatment of hypercoagulability in patients with diabetes mellitus (83). The administration of $200 \mathrm{mg} /$ day to diabetic patients was shown to significantly reduce the number of systemic PDMPs $(\sim 30 \%)$ and MDMPs $(\sim 20 \%)$, demonstrating potential to prevent cardiovascular complications associated with elevated MP production (141). However, like calcium channel blockers outlined above, these drugs were not able to reduce the amount of MP to a level comparable to that in healthy individuals.

\section{Pantethine/Cystamine}

Pantethine (Figure 4), a disulfide intermediate in the production of Coenzyme A, inhibits platelet aggregation in vitro and has been shown to downregulate TNF-activated MP release associated with $\mathrm{CM}$, by modulating an early step of the inflammation-coagulation cascade (86). Mouse brain endothelial cells, incubated with $1 \mathrm{mM}$ of pantethine for 24 hours showed a $51 \%$ reduction in MP formation, whilst in vivo mice treated with pantethine had no signs of the associated neurological syndrome and exhibited MP levels similar to uninfected mice (86). Cystamine (Figure 4), another low molecular weight disulfide, also showed comparable inhibition of MP formation in vitro, but induced toxic shock with pathogenic consequences in vivo (86). In contrast, pantethine was well tolerated and showed potential as an effective therapeutic agent (86).

The monomeric analogues of these molecules, pantetheine and cysteamine (Figure 4), were also investigated but proved to be ineffective, indicating that the disulfide bond is necessary for inhibition. As yet, the mechanism of pantethine MP inhibition has not been characterised.

\section{LMP-420}

During CM, TNF-activated endothelial MP formation can be reduced by treatment with the low molecular weight purine compound $\left(2-\mathrm{NH}_{2}-\right.$ 6-Cl-9-[(5-dihydroxyboryl)-pentyl] purine), also known a LMP-420 (Figure 4). LMP-420 is a novel TNF- $\alpha$ inhibitor that produces strong antiinflammatory effects and prevents cytokineinduced overproduction of MP release in response to activation by TNF- $\alpha$ as well as lymphotoxin- $\alpha$ (LT). MP release was shown to be significantly reduced in TNF- $\alpha$ or LT-activated human brainderived endothelial cells (HBEC-5i) that were treated with 50nM of LMP-420 (142).

As MPs presenting in $\mathrm{CM}$ are inextricably linked with the inflammation-coagulation cascade, the inhibition of their formation could lead to a new therapeutic approach for increasing CM patient survival rates (142).

\section{ROCK Inhibitors}

Rho-associated protein kinases (ROCKs) regulate the actin cytoskeleton, and have been implicated in cancer cell migration, tumour progression and formation of tumour-derived microvesicles (143). In light of this, ROCK inhibitors, such as Y27632 (Figure 4), have been developed as potential cancer therapies (144).

Y-27632, a low-molecular-weight inhibitor has been shown to reduce tumour-cell propagation in vivo and thus could potentially be used in cancer therapy $(93,145)$.

The treatment of HeLa cervical tumour cells, U87 brain tumour cells and MDA-MB-231 breast cancer cells with Y-27632 $(5 \mu \mathrm{M})$ was shown to significantly reduce the number of MPs produced through the ROCK-dependent signaling pathway 
as well as eliminating the appearance of microvesicles on the cell surface (143).

To date no ROCK inhibitors are used in clinical treatments of cancer, however data suggests they have the potential to reduce primary tumour growth, as well as reducing metastasis (144).

\section{CONCLUSIONS}

Since their discovery, MPs have been shown to play a significant role in a wide variety of diseases and infectious conditions besides their important function in normal cellular processes. Due to these deleterious effects, and common occurrence in such conditions, the inhibition of their formation presents an attractive treatment strategy. Inhibitors developed thus far have shown some promise in this field.

Down-regulation of MP production in patients with diabetes has been shown to improve vascular dysfunction and lower blood pressure, whilst in mouse models, pantethine has been shown to reverse the effects of CM-related neurological syndrome.

As MP production is inextricably linked to cancer progression, inhibiting their formation has the potential to interfere with the ability of the cancerous cells to proliferate, as well as their ability to confer MDR to sensitive cells.

In light of the potential therapeutic effects of MP inhibitors, this area of research requires further development, as there are currently no specific or potent MP inhibitors available for the treatment of disease. Due to the widespread occurrence of aberrant MP release in many conditions, the development of MP inhibitors thus holds promise in providing a novel treatment paradigm across numerous pathophysiologies.

\section{ACKNOWLEDGEMENTS}

The authors thank the following funding bodies for supporting this work: New South Wales Cancer Council (571016) and National Health and Medical Research Council (1007613).

\section{REFERENCES}

1. Deatherage BL, Cookson BT. Membrane Vesicle Release in Bacteria, Eukaryotes, and Archaea: a Conserved yet Underappreciated Aspect of Microbial Life. Infection and immunity. 2012;80(6):1948-57.

2. György B, Szabó TG, Pásztói M, Pál Z, Misják $\mathrm{P}$, Aradi B, et al. Membrane vesicles, current state-of-the-art: emerging role of extracellular vesicles. Cellular and molecular life sciences. 2011;68(16):2667-88.

3. Jaiswal R, Luk F, Dalla PV, Grau GER, Bebawy M. Breast Cancer-Derived Microparticles Display Tissue Selectivity in the Transfer of Resistance Proteins to Cells. PLoS ONE. 2013;8(4):e61515.

4. Jaiswal R, Luk F, Gong J, Mathys JM, Grau GER, Bebawy M. Microparticle conferred microRNA profiles-implications in the transfer and dominance of cancer traits. Molecular cancer. 2012;11(1):37-48.

5. Jimenez JJ, Jy W, Mauro LM, Soderland C, Horstman LL, Ahn YS. Endothelial cells release phenotypically and quantitatively distinct microparticles in activation and apoptosis. Thrombosis Research. 2003;109(4):175-80.

6. Gutiérrez-Vázquez C, Villarroya-Beltri C, Mittelbrunn M, Sánchez-Madrid F. Transfer of extracellular vesicles during immune cell-cell interactions. Immunological Reviews. 2013;251(1):125-42.

7. Wolf P. The nature and significance of platelet products in human plasma. British journal of haematology. 1967;13(3):269-88.

8. Théry C, Ostrowski M, Segura E. Membrane vesicles as conveyors of immune responses. Nature Reviews Immunology. 2009;9(8):581-93.

9. Morel O, Jesel L, Freyssinet JM, Toti F. Cellular mechanisms underlying the formation of circulating microparticles. Arteriosclerosis, thrombosis, and vascular biology. 2011;31(1):1526.

10. Antonyak MA, Li B, Boroughs LK, Johnson JL, Druso JE, Bryant KL, et al. Cancer cell-derived microvesicles induce transformation by transferring tissue transglutaminase and fibronectin to recipient cells. Proceedings of the National Academy of Sciences. 2011;108(12):4852-7.

11. Leroyer A, Tedgui A, Boulanger C. Role of microparticles in atherothrombosis. Journal of internal medicine. 2008;263(5):528-37.

12. Boilard E, Nigrovic PA, Larabee K, Watts GF, Coblyn JS, Weinblatt ME, et al. Platelets amplify inflammation in arthritis via collagen-dependent microparticle production. Science Signaling. 2010;327(5965):580-3.

13. Heijnen HF, Schiel AE, Fijnheer R, Geuze HJ, Sixma JJ. Activated Platelets Release Two Types of Membrane Vesicles: Microvesicles by Surface Shedding and Exosomes Derived From Exocytosis of Multivesicular Bodies and $\propto$ Granules. Blood. 1999;94(11):3791-9.

14. Doeuvre L, Plawinski L, Toti F, Anglés-Cano E. Cell-derived microparticles: a new challenge in neuroscience. Journal of Neurochemistry. 2009;110(2):457-68.

15. Morel O, Toti F, Hugel B, Bakouboula B, Camoin-Jau L, Dignat-George $\mathrm{F}$, et al. Procoagulant Microparticles Disrupting the 
Vascular Homeostasis Equation? Arteriosclerosis, thrombosis, and vascular biology. 2006;26(12):2594-604.

16. Pilzer D, Gasser O, Moskovich O, Schifferli JA, Fishelson Z. Emission of membrane vesicles: roles in complement resistance, immunity and cancer. Springer seminars in immunopathology. 2005;27(3):375-87.

17. Morel O, Toti F, Hugel B, Freyssinet JM. Cellular microparticles: a disseminated storage pool of bioactive vascular effectors. Current opinion in hematology. 2004;11(3):156-64.

18. Leroyer AS, Anfosso F, Lacroix R, Sabatier F, Simoncini S, Njock SM, et al. Endothelialderived microparticles: Biological conveyors at the crossroad of inflammation, thrombosis and angiogenesis. Thrombosis \& Haemostasis. 2010;104(3):456-63.

19. Higgins $\mathrm{CF}$. $\mathrm{ABC}$ transporters: from microorganisms to man. Annual review of cell biology. 1992;8(1):67-113.

20. Mack M, Kleinschmidt A, Bruhl H, Klier C, Nelson PJ, Cihak J, et al. Transfer of the chemokine receptor CCR5 between cells by membrane-derived microparticles: a mechanism for cellular human immunodeficiency virus 1 infection. Nature medicine. 2000;6(7):769-75.

21. Distler JHW, Huber LC, Gay S, Distler O, Pisetsky DS. Microparticles as mediators of cellular cross-talk in inflammatory disease. Autoimmunity. 2006;39(8):683-90.

22. Furie B, Furie BC. Mechanisms of thrombus formation. New England Journal of Medicine. 2008;359(9):938-49.

23. Bebawy M, Combes V, Lee E, Jaiswal R, Gong $\mathrm{J}$, Bonhoure A, et al. Membrane microparticles mediate transfer of P-glycoprotein to drug sensitive cancer cells. Leukemia. 2009;23(9):1643-9.

24. Zahra S, Anderson JAM, Stirling D, Ludlam CA. Microparticles, malignancy and thrombosis. British journal of haematology. 2011;152(6):688700 .

25. Hristov M, Erl W, Linder S, Weber PC. Apoptotic bodies from endothelial cells enhance the number and initiate the differentiation of human endothelial progenitor cells in vitro. Blood. 2004;104(9):2761-6.

26. Elmore S. Apoptosis: a review of programmed cell death. Toxicologic pathology. 2007;35(4):495-516.

27. Savill J, Dransfield I, Gregory C, Haslett C. A blast from the past: clearance of apoptotic cells regulates immune responses. Nature Reviews Immunology. 2002;2(12):965-75.

28. Holmgren L, Szeles A, Rajnavölgyi E, Folkman J, Klein G, Ernberg I, et al. Horizontal transfer of DNA by the uptake of apoptotic bodies. Blood. 1999;93(11):3956-63.

29. Bergsmedh A, Szeles A, Henriksson M, Bratt A, Folkman MJ, Spetz A-L, et al. Horizontal transfer of oncogenes by uptake of apoptotic bodies. Proceedings of the National Academy of Sciences. 2001;98(11):6407-11.

30. Azevedo LCP. Microparticles and Exosomes: Are They Part of Important Pathways in Sepsis Pathophysiology? Fernandez R, editor: InTech; 2012. 155-67 p.

31. Beyer C, Pisetsky DS. The role of microparticles in the pathogenesis of rheumatic diseases. Nature Reviews Rheumatology. 2009;6(1):21-9.

32. Henson PM, Bratton DL, Fadok VA. Apoptotic cell removal. Current Biology. 2001;11(19):R795-R805.

33. Coltel N, Combes V, Wassmer SC, Chimini G, Grau GE. Cell vesiculation and immunopathology: implications in cerebral malaria. Microbes and infection. 2006;8(8):230516.

34. Hurley JH, Boura E, Carlson L-A, Różycki B. Membrane budding. Cell. 2010;143(6):875-87.

35. Vidal M, Sainte-Marie J, Philippot JR, Bienvenue A. Asymmetric distribution of phospholipids in the membrane of vesicles released during in vitro maturation of guinea pig reticulocytes: Evidence precluding a role for "aminophospholipid translocase". Journal of Cellular Physiology. 1989;140(3):455-62.

36. Deregibus MC, Cantaluppi V, Calogero R, Iacono ML, Tetta $\mathrm{C}$, Biancone $\mathrm{L}$, et al. Endothelial progenitor cell-derived microvesicles activate an angiogenic program in endothelial cells by a horizontal transfer of mRNA. Blood. 2007;110(7):2440-8.

37. Valadi H, Ekström K, Bossios A, Sjöstrand M, Lee JJ, Lötvall JO. Exosome-mediated transfer of mRNAs and microRNAs is a novel mechanism of genetic exchange between cells. Nature cell biology. 2007;9(6):654-9.

38. Al-Nedawi K, Meehan B, Rak J. Microvesicles: messengers and mediators of tumor progression. Cell Cycle. 2009;8(13):2014-8.

39. Prado N, Marazuela EG, Segura E, FernándezGarcía H, Villalba M, Théry C, et al. Exosomes from bronchoalveolar fluid of tolerized mice prevent allergic reaction. The Journal of immunology. 2008;181(2):1519-25.

40. Andre F, Schartz NE, Movassagh M, Flament C, Pautier P, Morice $\mathrm{P}$, et al. Malignant effusions and immunogenic tumour-derived exosomes. Lancet. 2002;360(9329):295-305.

41. Admyre C, Johansson SM, Qazi KR, Filén J-J, Lahesmaa R, Norman M, et al. Exosomes with immune modulatory features are present in human breast milk. The Journal of immunology. 2007;179(3):1969-78.

42. Pisitkun T, Shen R-F, Knepper MA. Identification and proteomic profiling of exosomes in human urine. Proceedings of the National Academy of Sciences of the United States of America. 2004;101(36):13368-73. 
43. Caby M-P, Lankar D, Vincendeau-Scherrer C, Raposo G, Bonnerot C. Exosomal-like vesicles are present in human blood plasma. International immunology. 2005;17(7):879-87.

44. Dignat-George F, Boulanger CM. The many faces of endothelial microparticles. Arteriosclerosis, thrombosis, and vascular biology. 2011;31(1):27-33.

45. Montoro-García S, Shantsila E, Marín F, Blann A, Lip GYH. Circulating microparticles: new insights into the biochemical basis of microparticle release and activity. Basic research in cardiology. 2011;106(6):911-23.

46. Zwaal R, Comfurius P, Bevers E. Surface exposure of phosphatidylserine in pathological cells. Cellular and molecular life sciences. 2005;62(9):971-88.

47. Freyssinet JM. Cellular microparticles: what are they bad or good for? Journal of Thrombosis and Haemostasis. 2003;1(7):1655-62.

48. VanWijk MJ, VanBavel E, Sturk A, Nieuwland R. Microparticles in cardiovascular diseases. Cardiovascular research. 2003;59(2):277-87.

49. Combes V, Simon AC, Grau GE, Arnoux D, Camoin L, Sabatier F, et al. In vitro generation of endothelial microparticles and possible prothrombotic activity in patients with lupus anticoagulant. Journal of Clinical Investigation. 1999;104(1):93-102.

50. Sapet C, Simoncini S, Loriod B, Puthier D, Sampol J, Nguyen C, et al. Thrombin-induced endothelial microparticle generation: identification of a novel pathway involving ROCK-II activation by caspase-2. Blood. 2006;108(6):1868-76.

51. Szotowski B, Antoniak S, Goldin-Lang P, Tran Q-V, Pels K, Rosenthal P, et al. Antioxidative treatment inhibits the release of thrombogenic tissue factor from irradiation-and cytokineinduced endothelial cells. Cardiovascular research. 2007;73(4):806-12.

52. Comfurius P, Senden JMG, Tilly RHJ, Schroit AJ, Bevers EM, Zwaal RFA. Loss of membrane phospholipid asymmetry in platelets and red cells may be associated with calcium-induced shedding of plasma membrane and inhibition of aminophospholipid translocase. Biochimica et Biophysica Acta (BBA)-Biomembranes. 1990;1026(2):153-60.

53. Dachary-Prigent J, Pasquet JM, Freyssinet JM, Nurden AT. Calcium involvement in aminophospholipid exposure and microparticle formation during platelet activation: a study using Ca2+-ATPase inhibitors. Biochemistry. 1995;34(36):11625-34.

54. Smeets EF, Comfurius P, Bevers EM, Zwaal RF. Calcium-induced transbilayer scrambling of fluorescent phospholipid analogs in platelets and erythrocytes. Biochimica et Biophysica Acta (BBA)-Biomembranes. 1994;1195(2):281-6.
55. Piccin A, Murphy WG, Smith OP. Circulating microparticles: pathophysiology and clinical implications. Blood reviews. 2007;21(3):157-71.

56. Freyssinet JM, Toti F. Formation of procoagulant microparticles and properties. Thromb Res. 2010;125 Suppl 1(0):S46-8.

57. Burnier L, Fontana P, Kwak BR, AngelilloScherrer A. Cell-derived microparticles in haemostasis and vascular medicine. Thromb Haemost. 2009; 101(3):439-51.

58. Hugel B, Martínez MC, Kunzelmann C, Freyssinet JM. Membrane microparticles: two sides of the coin. Physiology. 2005;20(1):22-7.

59. Baron M, Boulanger CM, Staels B, Tailleux A. Cell-derived microparticles in atherosclerosis: biomarkers and targets for pharmacological modulation? Journal of Cellular and Molecular Medicine. 2012;16(7):1365-76.

60. Bevers EM, Comfurius P, Dekkers DWC, Zwaal RFA. Lipid translocation across the plasma membrane of mammalian cells. Biochimica et Biophysica Acta (BBA)-Molecular and Cell Biology of Lipids. 1999;1439(3):317-30.

61. Chang C-P, Zhao J, Wiedmer T, Sims P. Contribution of platelet microparticle formation and granule secretion to the transmembrane migration of phosphatidylserine. Journal of Biological Chemistry. 1993;268(10):7171-8.

62. Manno S, Takakuwa Y, Mohandas N. Identification of a functional role for lipid asymmetry in biological membranes: Phosphatidylserine-skeletal protein interactions modulate membrane stability. Proceedings of the National Academy of Sciences. 2002;99(4):19438.

63. Coleman ML, Sahai EA, Yeo M, Bosch M, Dewar A, Olson MF. Membrane blebbing during apoptosis results from caspase-mediated activation of ROCK I. Nature cell biology. 2001;3(4):339-45.

64. Bukowska A, Lendeckel U, Bode-Böger SM, Goette A. Physiologic and pathophysiologic role of calpain: implications for the occurrence of atrial fibrillation. Cardiovascular therapeutics. 2012;30(3):e115-e27.

65. Chakraborti S, Alam MN, Paik D, Shaikh S, Chakraborti T. Implications of calpains in health and diseases. Indian $\mathrm{J}$ Biochem Biophys. 2012;49(5):316-28.

66. Hanna RA, Campbell RL, Davies PL. Calciumbound structure of calpain and its mechanism of inhibition by calpastatin. Nature. 2008;456(7220):409-12.

67. Fox J, Austin C, Reynolds C, Steffen P. Evidence that agonist-induced activation of calpain causes the shedding of procoagulant-containing microvesicles from the membrane of aggregating platelets. Journal of Biological Chemistry. 1991;266(20):13289-95.

68. Pasquet JM, Dachary-Prigent J, Nurden AT. Calcium influx is a determining factor of calpain 
activation and microparticle formation in platelets. European Journal of Biochemistry. 1996;239(3):647-54.

69. Carragher N. Calpain inhibition: a therapeutic strategy targeting multiple disease states. Current pharmaceutical design. 2006;12(5):615-38.

70. Randriamboavonjy V, Fleming I. All cut up! The consequences of calpain activation on platelet function. Vascular Pharmacology. 2012;56(56):201-15.

71. Perrin B, Huttenlocher A. Calpain. The international journal of biochemistry \& cell biology. 2002;34(7):722-5.

72. Storr SJ, Carragher NO, Frame MC, Parr T, Martin SG. The calpain system and cancer. Nature Reviews Cancer. 2011;11(5):364-74.

73. Morel O, Morel N, Freyssinet JM, Toti F. Platelet microparticles and vascular cells interactions: a checkpoint between the haemostatic and thrombotic responses. Platelets. 2008;19(1):9-23.

74. Mostefai H, Andriantsitohaina R, Martinez M. Plasma membrane microparticles in angiogenesis: role in ischemic diseases and in cancer. Physiological research. 2008;57(3):31120.

75. Müller I, Klocke A, Alex M, Kotzsch M, Luther $\mathrm{T}$, Morgenstern E, et al. Intravascular tissue factor initiates coagulation via circulating microvesicles and platelets. The FASEB Journal. 2003;17(3):476-8.

76. Hrachovinová I, Cambien B, Hafezi-Moghadam A, Kappelmayer J, Camphausen RT, Widom A, et al. Interaction of P-selectin and PSGL-1 generates microparticles that correct hemostasis in a mouse model of hemophilia A. Nature medicine. 2003;9(8):1020-5.

77. Satta N, Freyssinet J-M, Toti F. The significance of human monocyte thrombomodulin during membrane vesiculation and after stimulation by lipopolysaccharide. British journal of haematology. 1997;96(3):534-42.

78. Pérez-Casal M, Downey C, Fukudome K, Marx $\mathrm{G}$, Toh $\mathrm{CH}$. Activated protein $\mathrm{C}$ induces the release of microparticle-associated endothelial protein C receptor. Blood. 2005;105(4):1515-22.

79. Lacroix R, Sabatier F, Mialhe A, Basire A, Pannell R, Borghi $\mathrm{H}$, et al. Activation of plasminogen into plasmin at the surface of endothelial microparticles: a mechanism that modulates angiogenic properties of endothelial progenitor cells in vitro. Blood. 2007;110(7):2432-9.

80. Hunter MP, Ismail N, Zhang X, Aguda BD, Lee EJ, $\mathrm{Yu}$ L, et al. Detection of microRNA expression in human peripheral blood microvesicles. PLoS One. 2008;3(11):e3694.

81. Fauci AS. Host factors and the pathogenesis of HIV-induced disease. Nature. 1996;384(6609):529-34.

82. WHO. Diabetes. 2011 [cited 2013]; Available from: http://www.who.int/mediacentre/factsheets/fs312 /en/print.html.

83. Nomura $\mathrm{S}$, Takahashi $\mathrm{N}$, Inami $\mathrm{N}$, Kajiura $\mathrm{T}$, Yamada K, Nakamori $\mathrm{H}$, et al. Probucol and ticlopidine: effect on platelet and monocyte activation markers in hyperlipidemic patients with and without type 2 diabetes. Atherosclerosis. 2004;174(2):329-35.

84. WHO. Malaria Fact sheet N94 2013 [cited 2013 16 May 2013]; Available from: http://www.who.int/mediacentre/factsheets/fs094 /en/index.html.

85. van der Heyde HC, Nolan J, Combes V, Gramaglia I, Grau GE. A unified hypothesis for the genesis of cerebral malaria: sequestration, inflammation and hemostasis leading to microcirculatory dysfunction. Trends in parasitology. 2006;22(11):503-8.

86. Penet MF, Abou-Hamdan M, Coltel N, Cornille E, Grau GE, De Reggi M, et al. Protection against cerebral malaria by the low-molecularweight thiol pantethine. Proceedings of the National Academy of Sciences. 2008;105(4):1321-6.

87. Schofield L, Grau GE. Immunological processes in malaria pathogenesis. Nature Reviews Immunology. 2005;5(9):722-35.

88. Mfonkeu JBP, Gouado I, Kuaté HF, Zambou O, Zollo PHA, Grau GER, et al. Elevated cellspecific microparticles are a biological marker for cerebral dysfunctions in human severe malaria. PLoS One. 2010;5(10):e13415.

89. Combes V, Coltel N, Alibert M, Van Eck M, Raymond C, Juhan-Vague I, et al. ABCA1 gene deletion protects against cerebral malaria: potential pathogenic role of microparticles in neuropathology. The American journal of pathology. 2005;166(1):295-302.

90. Combes V, El-Assaad F, Faille D, Jambou R, Hunt NH, Grau GER. Microvesiculation and cell interactions at the brain-endothelial interface in cerebral malaria pathogenesis. Progress in neurobiology. 2010;91(2):140-51.

91. Wassmer SC, Combes V, Grau GER. Platelets and microparticles in cerebral malaria: the unusual suspects. Drug Discovery Today: Disease Mechanisms. 2011;8(1-2):e15-e23.

92. Friend C, Marovitz W, Henle G, Henle W, Tsuei D, Hirschhorn K, et al. Observations on cell lines derived from a patient with Hodgkin's disease. Cancer Research. 1978;38(8):2581-91.

93. Van Doormaal F, Kleinjan A, Di Nisio M, Büller $\mathrm{H}$, Nieuwland R. Cell-derived microvesicles and cancer. Neth J Med. 2009;67(7):266-73.

94. Furie B, Furie BC. Thrombus formation in vivo. Journal of Clinical Investigation. 2005;115(12):3355-62.

95. Kim H, Song K, Park Y, Kang Y, Lee Y, Lee K, et al. Elevated levels of circulating platelet microparticles, VEGF, IL-6 and RANTES in patients with gastric cancer: possible role of a 
metastasis predictor. European Journal of Cancer. 2003;39(2):184-91.

96. Abid Hussein MN, Boing AN, Sturk A, Hau CM, Nieuwland R. Inhibition of microparticle release triggers endothelial cell apoptosis and detachment. Thromb Haemost. 2007;98(5):1096107.

97. Inal JM, Ansa-Addo EA, Stratton D, Kholia S, Antwi-Baffour SS, Jorfi S, et al. Microvesicles in health and disease. Archivum immunologiae et therapiae experimentalis. 2012:1-15.

98. Graves LE, Ariztia EV, Navari JR, Matzel HJ, Stack MS, Fishman DA. Proinvasive properties of ovarian cancer ascites-derived membrane vesicles. Cancer Research. 2004;64(19):7045-9.

99. Rak J, Guha A. Extracellular vesicles-vehicles that spread cancer genes. Bioessays. 2012;34(6):489-97.

100. Jaiswal R, Gong J, Sambasivam S, Combes V, Mathys J-M, Davey R, et al. Microparticleassociated nucleic acids mediate trait dominance in cancer. The FASEB Journal. 2012;26(1):4209.

101. Gong J, Jaiswal R, Mathys JM, Combes V, Grau G, Bebawy M. Microparticles and their emerging role in cancer multidrug resistance. Cancer treatment reviews. 2012;38(3):226-34.

102. Zaman G, Flens M, Van Leusden M, De Haas M, Mülder H, Lankelma J, et al. The human multidrug resistance-associated protein MRP is a plasma membrane drug-efflux pump. Proceedings of the National Academy of Sciences. 1994;91(19):8822-6.

103. Sharom FJ. ABC multidrug transporters: structure, function and role in chemoresistance. Pharmacogenomics. 2008;9(1):105-27.

104. Gong YP, Liu T, Jia YQ, Qin L, Deng CQ, Yang RYO. Comparison of Pgp-and MRP-mediated multidrug resistance in leukemia cell lines. International journal of hematology. 2002; 75(2):154-60.

105. Pasquier J, Galas L, Boulangé-Lecomte C, Rioult D, Bultelle F, Magal P, et al. Different Modalities of Intercellular Membrane Exchanges Mediate Cell-to-cell P-glycoprotein Transfers in MCF-7 Breast Cancer Cells. Journal of Biological Chemistry. 2012;287(10):7374-87.

106. Longo-Sorbello G, Bertino JR. Current understanding of methotrexate pharmacology and efficacy in acute leukemias. Use of newer antifolates in clinical trials. haematologica. 2001;86(2):121-7.

107. Lage H. An overview of cancer multidrug resistance: A still unsolved problem. Cellular and molecular life sciences. 2008;65(20):3145-67.

108. Ganapathi R, Grabowski D, Turinic R, Valenzuela R. Correlation between potency of calmodulin inhibitors and effects on cellular levels and cytotoxic activity of doxorubicin (adriamycin) in resistant P388 mouse leukemia cells. European Journal of Cancer and Clinical Oncology. 1984;20(6):799-806.

109. Hollt V, Kouba M, Dietel M, Vogt G. Stereoisomers of calcium antagonists which differ markedly in their potencies as calcium blockers are equally effective in modulating drug transport by P-glycoprotein. Biochemical Pharmacology. 1992;43(12):2601-8.

110. Tsuruo $\mathrm{T}$, Iida $\mathrm{H}$, Tsukagoshi $\mathrm{S}$, Sakurai $\mathrm{Y}$. Overcoming of vincristine resistance in P388 leukemia in vivo and in vitro through enhanced cytotoxicity of vincristine and vinblastine by verapamil. Cancer Research. 1981;41(5):196772.

111. Nooter K, Oostrum R, Deurloo J. Effects of verapamil on the pharmacokinetics of daunomycin in the rat. Cancer chemotherapy and pharmacology. 1987;20(2):176-8.

112. Ozols RF, Cunnion RE, Klecker Jr RW, Hamilton TC, Ostchega Y, Parrillo JE, et al. Verapamil and adriamycin in the treatment of drug-resistant ovarian cancer patients. Journal of Clinical Oncology. 1987;5(4):641-7.

113. Gottesman MM, Pastan I, Ambudkar SV. Pglycoprotein and multidrug resistance. Current opinion in genetics \& development. 1996;6(5):610-7.

114. Gottesman MM. Mechanisms of cancer drug resistance. Annual review of medicine. 2002;53(1):615-27.

115. Rustom A, Saffrich R, Markovic I, Walther P, Gerdes HH. Nanotubular highways for intercellular organelle transport. Science. 2004;303(5660):1007-10.

116. Levchenko A, Mehta BM, Niu X, Kang G, Villafania L, Way D, et al. Intercellular transfer of P-glycoprotein mediates acquired multidrug resistance in tumor cells. Proceedings of the National Academy of Sciences of the United States of America. 2005;102(6):1933-8.

117. Barteneva NS, Fasler-Kan E, Bernimoulin M, Stern JN, Ponomarev ED, Duckett L, et al. Circulating microparticles: square the circle. BMC Cell Biol. 2013;14(1):23.

118. Donkor IO. Calpain inhibitors: a survey of compounds reported in the patent and scientific literature. Expert opinion on therapeutic patents. 2011;21(5):601-36.

119. Rendu F, Brohard-Bohn B, Pain S, BachelotLoza C, Auger J. Thiosulfinates inhibit platelet aggregation and microparticle shedding at a calpain-dependent step. THROMBOSIS AND HAEMOSTASIS-STUTTGART-. 2001;86(5):1284-91.

120. Sorimachi H, Ishiura S, Suzuki K. Structure and physiological function of calpains. Biochemical Journal. 1997;328(Pt 3):721-32.

121. Harbeson SL, Abelleira SM, Akiyama A, Barrett III R, Carroll RM, Straub JA, et al. Stereospecific Synthesis of Peptidyl. alpha.-Keto Amides as 
Inhibitors of Calpain. Journal of Medicinal Chemistry. 1994;37(18):2918-29.

122. Li Z, Ortega-Vilain A-C, Patil GS, Chu D-L, Foreman J, Eveleth DD, et al. Novel peptidyl $\alpha$ keto amide inhibitors of calpains and other cysteine proteases. Journal of Medicinal Chemistry. 1996;39(20):4089-98.

123. Tamai M, Hanada K, Adachi T, Oguma K, Kashiwagi K, Omura S, et al. Papain inhibitions by optically active E-64 analogs. J Biochem. 1981;90(1):255-7.

124. Giordano C, Gallina C, Consalvi V, Scandurra R. Irreversible inactivation of papain and cathepsin $\mathrm{B}$ by epoxidic substrate analogues. European journal of medicinal chemistry. 1990;25(6):47987.

125. Sugita $H$, Ishiura $\mathrm{S}$, Suzuki $\mathrm{K}$, Imahori $\mathrm{K}$. Inhibition of epoxide derivatives on chicken calcium-activated neutral protease (CANP) in vitro and in vivo. J Biochem. 1980;87(1):339-41.

126. Shirasaki Y, Nakamura M, Yamaguchi M, Miyashita H, Sakai O, Inoue J. Exploration of orally available calpain inhibitors 2: peptidyl hemiacetal derivatives. Journal of Medicinal Chemistry. 2006;49(13):3926-32.

127. Donkor I. A survey of calpain inhibitors. Current Medicinal Chemistry. 2000;7(12):1171-88.

128. Inoue J, Nakamura M, Cui Y-S, Sakai Y, Sakai O, Hill JR, et al. Structure-activity relationship study and drug profile of N-(4fluorophenylsulfonyl)-L-valyl-L-leucinal (SJA6017) as a potent calpain inhibitor. Journal of Medicinal Chemistry. 2003;46(5):868-71.

129. Todd B, Moore D, Deivanayagam C, Lin G-d, Chattopadhyay D, Maki M, et al. A structural model for the inhibition of calpain by calpastatin: crystal structures of the native domain VI of calpain and its complexes with calpastatin peptide and a small molecule inhibitor. Journal of molecular biology. 2003;328(1):131-46.

130. Wang KK, Nath R, Posner A, Raser KJ, BurokerKilgore M, Hajimohammadreza I, et al. An alpha-mercaptoacrylic acid derivative is a selective nonpeptide cell-permeable calpain inhibitor and is neuroprotective. Proc Natl Acad Sci U S A. 1996;93(13):6687-92.

131. Croce K, Flaumenhaft R, Rivers M, Furie B, Furie BC, Herman IM, et al. Inhibition of calpain blocks platelet secretion, aggregation, and spreading. Journal of Biological Chemistry. 1999;274(51):36321-7.

132. Fox J, Reynolds CC, Austin CD. The role of calpain in stimulus-response coupling: evidence that calpain mediates agonist-induced expression of procoagulant activity in platelets. Blood. 1990;76(12):2510-9.
133. Goll DE, Thompson VF, Li H, Wei W, CONG J. The calpain system. Physiological reviews. 2003;83(3):731-801.

134. Badol P, David-Dufilho M, Auger J, Whiteheart SW, Rendu F. Thiosulfinates modulate platelet activation by reaction with surface free sulfhydryls and internal thiol-containing proteins. Platelets. 2007;18(7):481-90.

135. Kendler BS. Garlic (Allium sativum) and onion (Allium cepa): A review of their relationship to cardiovascular disease. Preventive medicine. 1987; 16(5):670-85.

136. Lee YJ, Jy W, Horstman LL, Janania J, Reyes Y, Kelley RE, et al. Elevated platelet microparticles in transient ischemic attacks, lacunar infarcts, and multiinfarct dementias. Thrombosis Research. 1993;72(4):295-304.

137. Nomura S, Ozaki Y, Ikeda Y. Function and role of microparticles in various clinical settings. Thrombosis Research. 2008;123(1):8-23.

138. Nomura $\mathrm{S}$, Inami $\mathrm{N}$, Kimura $\mathrm{Y}$, Omoto $\mathrm{S}$, Shouzu A, Nishikawa M, et al. Effect of nifedipine on adiponectin in hypertensive patients with type 2 diabetes mellitus. Journal of human hypertension. 2006;21(1):38-44.

139. Nomura S, Shouzu A, Omoto S, Nishikawa M, Iwasaka T. Benidipine improves oxidized LDLdependent monocyte and endothelial dysfunction in hypertensive patients with type 2 diabetes mellitus. Journal of human hypertension. 2005;19(7):551-7.

140. Robinson RA, Worfolk L, Tracy P. Endotoxin enhances the expression of monocyte prothrombinase activity. Blood. 1992;79(2):40616.

141. Shouzu A, Nomura S, Omoto S, Hayakawa T, Nishikawa M, Iwasaka T. Effect of ticlopidine on monocyte-derived microparticles and activated platelet markers in diabetes mellitus. Clinical and Applied 2004;10(2):167-73.

Thrombosis/Hemostasis.

142. Wassmer SC, Cianciolo GJ, Combes V, Grau GE. Inhibition of endothelial activation: a new way to treat cerebral malaria? PLoS medicine. 2005;2(9):e245.

143. Antonyak MA, Wilson KF, Cerione RA. $\mathrm{R}(\mathrm{h})$ oads to microvesicles. Small GTPases. 2012;3(4):219-24.

144. Morgan-Fisher M, Wewer UM, Yoneda A. Regulation of ROCK activity in cancer. J Histochem Cytochem. 2013;61(3):185-98.

145. Liao JK, Seto M, Noma K. Rho kinase (ROCK) inhibitors. J Cardiovasc Pharmacol. 2007;50(1):17-24. 